\title{
Modulation of gonadotrophin induced steroidogenic enzymes in granulosa cells by d-chiroinositol
}

Sandro Sacchi ${ }^{1}$, Federica Marinaro ${ }^{1}$, Debora Tondelli ${ }^{1}$, Jessica Lui ${ }^{1}$, Susanna Xella ${ }^{1}$, Tiziana Marsella ${ }^{1}$, Daniela Tagliasacchi ${ }^{1}$, Cindy Argento ${ }^{1}$, Alessandra Tirelli ${ }^{1}$, Simone Giulini ${ }^{1}$ and Antonio La Marca ${ }^{2 *}$

\begin{abstract}
Background: $d$-chiroinositol (DCI) is a inositolphosphoglycan (IPG) involved in several cellular functions that control the glucose metabolism. DCI functions as second messenger in the insulin signaling pathway and it is considered an insulin sensitizer since deficiency in tissue availability of $\mathrm{DCl}$ were shown to cause insulin resistance (IR). Polycystic ovary syndrome (PCOS) is a pathological condition that is often accompanied with insulin resistance. DCl can positively affects several aspect of PCOS etiology decreasing the total and free testosterone, lowering blood pressure, improving the glucose metabolism and increasing the ovulation frequency. The purpose of this study was to evaluate the effects of $\mathrm{DCl}$ and insulin combined with gonadotrophins namely follicle-stimulating hormone (FSH) and luteinizing hormone (LH) on key steroidogenic enzymes genes regulation, cytochrome P450 family 19 subfamily A member 1 (CYP19A1) and cytochrome P450 side-chain cleavage (P450sCC) in primary cultures of human granulosa cells ( $h G C s$ ). We also investigated whether DCl, being an insulin-sensitizer would be able to counteract the expected stimulator activity of insulin on human granulosa cells (hGCs).

Methods: The study was conducted on primary cultures of hGCs. Gene expression was evaluated by RT-qPCR method. Statistical analysis was performed applying student $t$-test, as appropriate $(P<0.05)$ set for statistical significance.
\end{abstract}

Results: DCI is able to reduce the gene expression of CYP19A1, P450sCc and insulin-like growth factor 1 receptor $(I G F-1 R)$ in dose-response manner. The presence of DCl impaired the increased expression of steroidogenic enzyme genes generated by the insulin treatment in gonadotrophin-stimulated hGCs.

Conclusions: Insulin acts as co-gonadotrophin increasing the expression of steroidogenic enzymes genes in gonadotrophin-stimulated granulosa cells. DCI is an insulin-sensitizer that counteracts this action by reducing the expression of the genes CYP19A1, P450sCC and IGF-1R. The ability of DCI to modulate in vitro ovarian activity of insulin could in part explain its beneficial effect when used as treatment for conditions associated to insulin resistance.

Keywords: d-chiroinositol, Steroiodogenesis, Insulin resistance

Abbreviations: ASRM, American Society for Reproductive Medicine; CAT, Chlamydia antibody testing; CYP19A1, Cytochrome P450 family 19 subfamily a member 1; P450scc, Cytochrome P450 side-chain cleavage; DCI, d-chiroinositol; DPBS, Dulbecco's phosphate buffered saline; ESHRE, European Society for Human Reproduction and Embryology; FBS, Foetal bovine serum; FSH, Follicle-stimulating hormone; GnRH, Gonadotrophin-releasing (Continued on next page)

\footnotetext{
* Correspondence: antlamarca@libero.it

${ }^{2}$ University of Modena and Reggio Emilia and Clinica Eugin Modena,

Modena, Italy

Full list of author information is available at the end of the article
} 


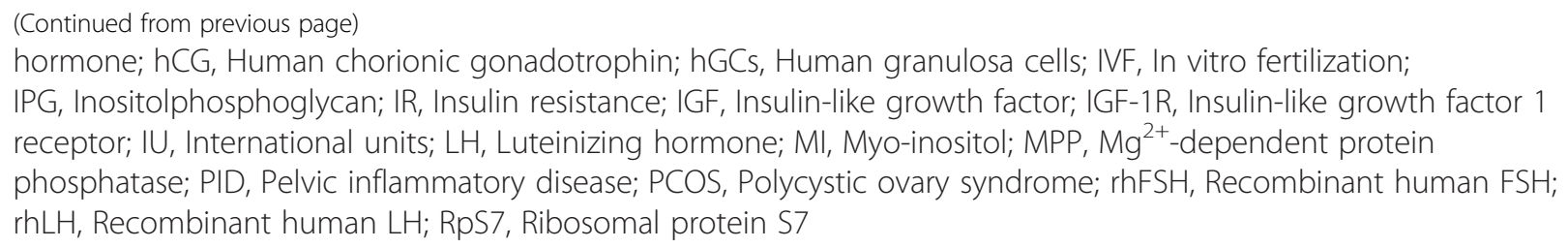

\section{Background}

The cis-1, 2, 4-trans-3, 5, 6-Cyclohexanehexol, also known as d-chiroinositol (DCI), is a six-carbon polyalcohol which belongs to the family collectively referred to as inositol which is a part of the B vitamin family. At cellular level inositols are incorporated into cell membranes as phosphatidyl-myo-inositol, the precursor of inositol triphosphate which acts as second messenger and regulates the activities of different hormones such as follicle-stimulating hormone (FSH) and insulin [1]. Epimerase enzymes convert inositols to up to nine stereoisomers including myo-inositol (MI) and DCI while the majority of the other stereoisomers generated fail to show an evident biological activity [2]. MI and DCI are both endogenous biosynthesized and introduced from dietary sources such as buckwheat [3], Cucurbita ficifolia [4] and soy lecithin [5].

DCI is considered as an insulin sensitizer since inositolphosphoglycan (IPG) mediators are involved in several cellular functions that control the glucose metabolism [6, 7].

Moreover, impaired metabolism of IPG mediators as well as a deficiency in tissue availability of inositol were shown to cause insulin resistance $[8,9]$.

Since DCI is synthetized by an epimerase that converts in vivo MI to DCI, several studies observed that a decreased DCI in urine as well as tissues of human subjects and animals with type 2 diabetes was accompanied by an increase in MI content $[10,11]$.

Additional investigations demonstrated that the altered inositol excretion patterns in human and monkey urine were specifically related to the underlying insulin resistance (IR), rather than to the diabetes type. To explain the altered pattern of urine inositol excretion observed under IR, a defect in the epimerization process was hypothesized.

When IR occurs, the conversion rate is affected, resulting in a decreased level of DCI in cells.

In 2003 the European Society for Human Reproduction and Embryology (ESHRE) and the American Society for Reproductive Medicine (ASRM) established that patients can be affected by polycystic ovary syndrome (PCOS) when at least two conditions as anovulation or hyperandrogenism or increased ovarian volume are verified at the same time. However, PCOS patients are often affected by IR and it was hypothesized that a DCI deficiency, which functions as second messanger in the insulin signaling pathway [12], can be related to IR [13].

It has been demonstrated that DCI can positively affects several aspect of PCOS etiology $[8,14]$. In these studies DCI was able to decrease the total and free testosterone, to lower blood pressure acting as insulin sensitizer by improving the glucose metabolism, and finally to increase the ovulation frequency $[8,14,15]$.

Insulin has been reported to be able to interact with steroidogenic enzymes in granulosa and luteinic cells of the ovaries [16-20]. Specifically insulin seems to potentiate the FSH and luteinizing hormone (LH) induction of cytochrome P450 family 19 subfamily A member 1 (CYP19A1) aromatase and this effect has been shown to be so evident that insulin is considered by many as a co-gonadotrophin $[17-19,21]$. The co-treatment, in vitro, with insulin-sensitizers, such as metformin or thiazelinediones, counteracts the potent action of insulin on human granulosa cells (hGCs) enzymes hence showing the relevance of insulin activity for ovarian cells physiology [16-21].

The objective of this study was to expand on this argument, hence investigating the possible effect of insulin on the ovarian response to both the two gonadotrophins FSH and LH. We specifically investigated the modifications of the gene expression of two key genes in steroidogenesis, the aromatase CYP19A1 and cytochrome P450 side-chain cleavage (P450scc). We also evaluated whether DCI, being an insulin-sensitizer would be able to counteract the expected stimulator activity of insulin on hGCs.

\section{Methods}

\section{Selection criteria}

Patients selected $(n=8)$ for this study were heathy, had regular menstrual cycles and had a mean age of $34( \pm 8)$. Patients underwent in vitro fertilization (IVF) because of male infertility. Clinical exclusion criteria adopted were: previous ovarian surgery, positivity for Chlamydia antibody testing (CAT), presence of ovarian cysts, history of pelvic inflammatory disease (PID), any known metabolic or endocrinological disease.

Patients underwent IVF cycles according the gonadotrophin-releasing hormone $(\mathrm{GnRH})$ antagonist protocol. Patients received recombinant human FSH (rhFSH, Gonal $\mathrm{F}^{\bullet}$, Merck Serono, Italy or Puregon ${ }^{\circ}$, 
MSD Organon, Italy) at a dose of at least 150 international units (IU) a day subcutaneously from day 2 or 3 of a spontaneous menstrual cycle. The GnRH antagonist, Ganirelix (Orgalutran, Schering-Plough) or Cetrorelix (Cetrotide, Merck Serono, Italy), was next administered daily by subcutaneous injection $(0.25 \mathrm{mg} / \mathrm{d})$ from the day of the stimulation cycle when the first follicle reached $14 \mathrm{~mm}$ in size to the day of human chorionic gonadotrophin (hCG) administration. When follicles reached $\geq 18 \mathrm{~mm}, 10000$ IU of hCG were administrated intramuscularly and 34-36 h later follicles were aspirated under patient sedation. hGCs were isolated from ovarian follicles of women undergoing oocyte retrieval for IVF protocol. Study approval was obtained from the local ethics committee and informed, written consent was obtained from each patient.

\section{Granulosa-lutein cell isolation and primary cell culture} hGCs were purified by centrifugation through a discontinuos Percoll (Amersham, Sweden) gradient as indicated in [22], and cultured individually in 24 wells plate $\left(50 \times 10^{3}\right.$ cells/well) in McCoy 5A medium (Carlo Erba, Italy) supplemented with $5 \%$ foetal bovine serum (FBS) South America (EU Approved, Carlo Erba, Italy), 2mM LGlutamine, $1 \%$ Penicillin/Streptomicin and 1\% Amphotericin B (Sigma Aldrich, St. Louis, MO, USA). Primary hGCs culture were mantained at $37^{\circ} \mathrm{C}$ under a controlled atmosphere of $5 \% \mathrm{CO}_{2}$ for 6 days to avoid side effect due to IVF hormones treatment, and subjected to medium changes with fresh culture medium daily.

\section{Treatments}

hGCs primary cultures were initially incubated in starvation medium (McCoy 5A medium supplemented with $0.1 \%$ FBS South America without antibiotics) for $12 \mathrm{~h}$ to synchronize cells before the treatments. hGCs were then incubated for $24 \mathrm{~h}$ with $0,1 \mathrm{IU} / \mathrm{ml}$ of long-acting insulin (Levemir ${ }^{\odot}$, Novo Nordisk, Denmark). hGCs insulin-treated where additionally incubated with 20 nM or $10 \mathrm{nM}$ DCI (LJ Pharma, Italy) alone or in combination with either $5 \mu \mathrm{M}$ rhFSH, (Gonal-F ${ }^{\oplus}$, Merck Serono, Italy) or $5 \mu \mathrm{M}$ of recombinant human $\mathrm{LH}$ (rhLH, Luveris ${ }^{\oplus}$, Merck Serono, Italy) for further $24 \mathrm{~h}$. DCI and gonadotrophins were dissolved into starvation medium. Experiments were repeated in triplicate. Negative controls using corresponding amount of vehicle control for insulin treatment and for each of gonadotrophin used were performed. Comparison between negative controls performed and untreated cells showed no differences in terms of cells vitality, toxic effects or impaired gene expression caused directly by the vehicle in which substances were dissolved.

\section{Trypan blue exclusion test of cell viability}

To assess the viability of gonadotrophin treated hGCs primary cultures, the Trypan Blue (Sigma Aldrich, St. Louis, MO, USA) exclusion test was performed. hGCs corresponding to each treatment and controls were submerged in $0.4 \%$ Trypan Blue in $1 \mathrm{X}$ Dulbecco's phosphate buffered saline (DPBS, Sigma Aldrich, St. Louis, MO, USA) solution directly in the wells then immediately counted $(n=200)$ under inverted microscope PrimoVert (Carl Zeiss Microscopy GmbH, Germany). Percentage of viable cells were calculated and expressed as ratio between blue-stained dead cells and not colored viable cells.

\section{Evaluation of gene expression by RT-qPCR}

Collected hGCs after each treatment were immediately processed for total RNA extraction using commercial product Tri-Reagent ${ }^{\circledR}$ (Sigma Aldrich, St Louis, MO, USA) following the manufacturer protocol. After an optional DNase I (Promega, Madison, WI, USA) digestion of $30 \mathrm{~min}$ at $37{ }^{\circ} \mathrm{C}$ the extracted RNA was evaluated and quantified by spectrophotometry using Nanodrop ND1000 (Thermo Fisher Scientific, Waltham, MA, USA) and $2 \mu \mathrm{g}$ of RNA of each sample was reverse transcribed to cDNA using iScript ${ }^{\mathrm{TM}}$ cDNA Synthesis Kit (Bio-Rad, Hercules, CA, USA) according to datasheet. $2 \mu \mathrm{L}$ of cDNA of each sample was tested in triplicate in RTqPCR using SsoAdvanced Universal SYBR ${ }^{\circ}$ Green Supermix (Bio-Rad, Hercules, CA, USA) following the conditions suggested by the manufacturer's protocol. Primers used (listed in Table 1) in RT-qPCR reaction were designed, where possible, across the intron to avoid gDNA contaminants amplification. All primers used has similar melting temperature so the general thermal profile of the reaction is for all the genes tested $30 \mathrm{~s}$ at $95{ }^{\circ} \mathrm{C}$ to initially activate the enzyme followed by 40 cycles of $95^{\circ} \mathrm{C}$ for $5 \mathrm{~s}$ and $60{ }^{\circ} \mathrm{C}$ for $20 \mathrm{~s}$ for each cycle. Results were normalized by using the reference gene Ribosomal protein $S 7$ $(R p S 7)$ gene. The specificity of each assay was validated by dissociation curve analysis and amplicons were separated by gel electrophoresis and imaged. Assay performance was validated by evaluating amplification efficiencies by means of calibration curves, and ensuring that the plot of log input amount versus DCq (also known as DCT) has a slope. Each reaction was repeated in triplicate. Negative control reactions omitted templates.

\section{Statistical analysis}

Statistical analysis was performed applying student $t$-test, as appropriate $(P<0.05)$ set for statistical significance. The relative expression of each gene has been evaluated using the $2^{-\Delta \Delta C t}$ method [23] and was calculated as the relative ratio in comparison to the first control sample, set arbitrarily to 1 . 
Table 1 Primers list used in RT-qPCR

\begin{tabular}{|c|c|c|c|c|}
\hline Gene & Protein name & Sequence $5^{\prime}-3^{\prime}$ & Amplicon lenght (bp) & NCBI Ref. sequence \\
\hline \multirow[t]{2}{*}{ RpS7 } & \multirow[t]{2}{*}{ Ribosomal protein S7 } & F: AATCTITGTTCCCGTTCCTCA & \multirow[t]{2}{*}{135} & \multirow[t]{2}{*}{ NM_001011.3 } \\
\hline & & R: CGAGTTGGCTTAGGCAGAA & & \\
\hline \multirow[t]{2}{*}{$\beta 3$ integrin } & \multirow[t]{2}{*}{$\beta 3$ integrin } & F: GACAAGGGCTCTGGAGACAG & \multirow[t]{2}{*}{233} & \multirow[t]{2}{*}{ NM_000212.2 } \\
\hline & & R: ACTGGTGAGCTTCGCATCT & & \\
\hline \multirow[t]{2}{*}{ IGFIR } & \multirow[t]{2}{*}{ Insulin-like growth factor 1 receptor } & F: CGTGGGAGGGTTGGTGATTA & \multirow[t]{2}{*}{161} & \multirow[t]{2}{*}{ NM_000875.3 } \\
\hline & & R: TGGCCACTCTGGTTTCAGGT & & \\
\hline \multirow[t]{2}{*}{ CYP19A1 } & \multirow[t]{2}{*}{ Aromatase } & F: CCCTTCTGCGTCGTGTCAT & \multirow[t]{2}{*}{86} & \multirow[t]{2}{*}{ NM_000103.3 } \\
\hline & & R: GATTTTAACCACGATAGCACTTTCG & & \\
\hline \multirow[t]{2}{*}{ P450scc (CYP11A1) } & \multirow[t]{2}{*}{ Cholesterol side-chain cleavage enzyme } & F: ACCAAGAACTTITTGCCCCT & \multirow[t]{2}{*}{127} & \multirow[t]{2}{*}{ NM_000781.2 } \\
\hline & & R: ATGTCCCCCGAGTAATTTCC & & \\
\hline
\end{tabular}

\section{Results}

To investigate a possible role of DCI as modulator of gene expression, hGCs primary culture were treated for $24 \mathrm{~h}$ with increasing concentrations of DCI dissolved into starvation medium. In order to assess the cell viability at the end of the DCI treatment the Trypan Blue exclusion test was performed while the $\beta 3$ integrin gene activation, expressed as ratio normalized by $R p S 7$ reference gene on RT-qPCR assay, was studied as positive control (Fig. 1).

At all concentrations of DCI tested the calculated precentage of viable hGCs was higher than $95 \%$ without any remarkable difference among treatments and in comparison to the untreated hGCs control (data not shown). As Fig. 1 shows, DCI is able to directly decrease the $\beta 3$ integrin gene expression of hGCs in a dose-response manner. DCI-treated primary cultures of hGCs that failed to show decrease of $\beta 3$ integrin gene expression were excluded from further analysis.

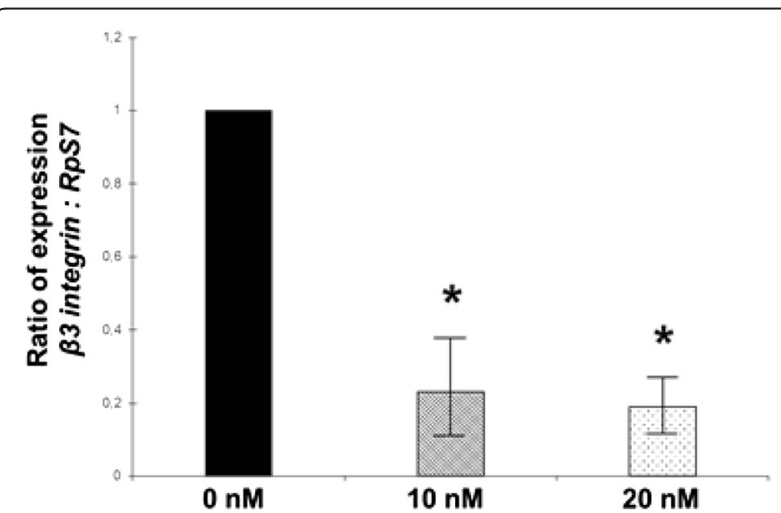

Fig. 1 Effect of $24 \mathrm{~h}$ incubation with increasing dosage of $\mathrm{DCl}$, range $0 \mathrm{nM}$ - $20 \mathrm{nM}$, on $\beta 3$ integrin gene expression normalized by the reference RpS7 gene in primary culture of hCGs in vitro by RTqPCR. Significant differences versus the respective controls were marked by * $p<0.05$, Student's $t$-test

\section{d-chiroinositol affects the steroidogenic enzymes gene} expression

The effect of $24 \mathrm{~h}$ incubation with increasing dosages of DCI on steroidogenic enzymes gene activation in primary cultures of hGCs was studied by RT-qPCR and expressed as ratio normalyzed by $R p S 7$ reference gene. Figure 2 shows the dose-response curve generated by different concentrations of DCI on CYP19A1 (Fig. 2a) and P450scc (Fig. 2b) gene expression.

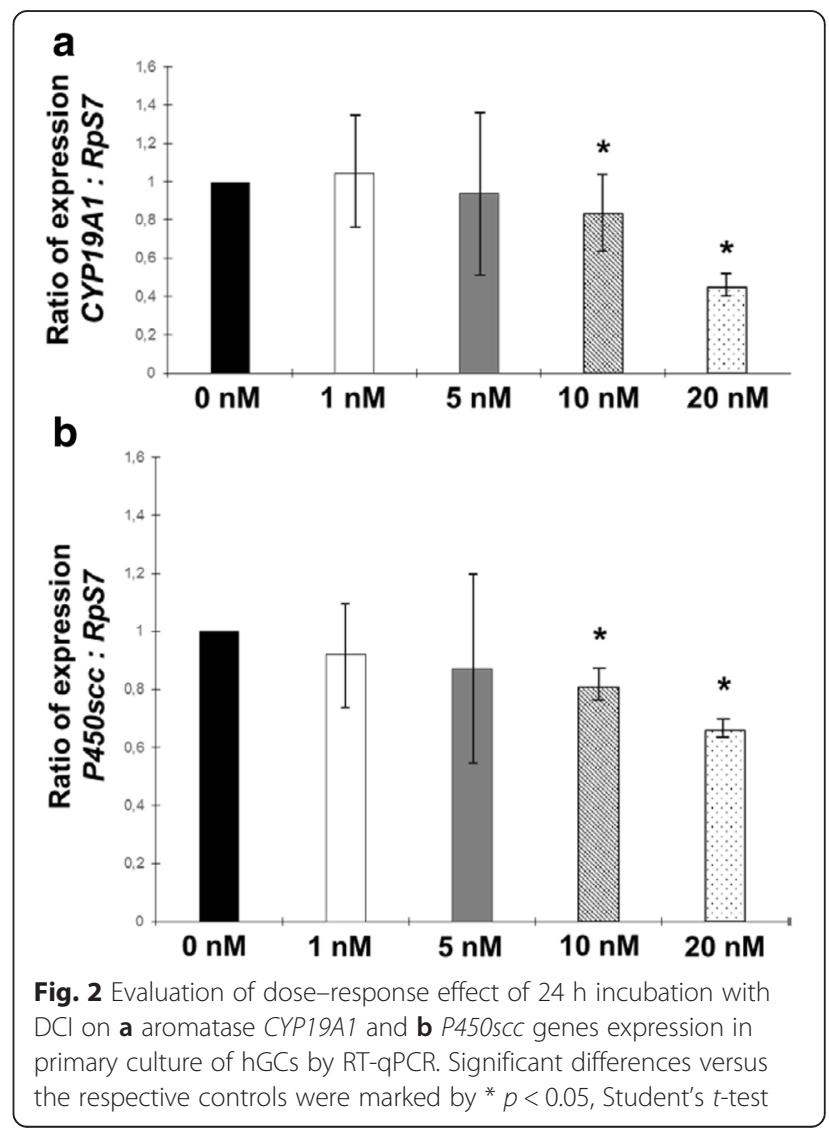


DCI has tendency to decrease the expression of both genes analyzed at the lowest concentrations tested and this effect is particularly significative with higher DCI dosages which were choosen and employed for following experiments.

\section{The insulin up-regulation of the steroidogenic enzyme genes response to gonadotrophins is balanced by d-chiroinositol treatment}

Primary cultures of hGCs were treated with gonadotrophins alone and in combination with $0,1 \mathrm{IU} / \mathrm{ml}$ insulin or $20 \mathrm{nM}$ DCI or both. Steroidogenic enzymes gene expression was calculated by RT-qPCR reactions and expressed as ratio normalyzed by $R p S 7$ refrence gene. The addition of $5 \mathrm{ng} / \mathrm{ml} \mathrm{rhFSH}$ (Fig. 3) or $5 \mathrm{ng} / \mathrm{ml} \mathrm{rhLH}$ (Fig. 4) was associated to a significant activation of gene expression of both CYP19A1 and P450scc. Expectantly, the co-incubation of gonadotrophins with $0,1 \mathrm{IU} / \mathrm{ml}$ of insulin resulted significantly more effective in inducing the two genes when compared to rhFSH alone (Fig. 3a, b) and rhLH alone (Fig. 4a). When added in the cultural system, the samples incubated with $20 \mathrm{nM}$ DCI show no significative differences if compared with the effect generated by gonadotrophin alone treatment (Figs. 3 and 4).
Meanwhile, the positive contribution of insulin to the steroidogenic genes induction generated by gonadotrophins is impaired by DCI co-incubation.

Finally both concentrations of DCI tested $(10 \mathrm{nM}$ or $20 \mathrm{nM}$ ) revealed that DCI is able to directly reduce insulin-like growth factor 1 receptor (IGF-1R) gene expression while the co-incubation of DCI and $0,1 \mathrm{U}$ of insulin in the culture system is not producing significatively differences between treated and untreated hGCs controls (Fig. 5).

\section{Discussion}

In the present study we demonstrated that insulin and DCI are able to affect directly the gene expression of two pivotal steroidogenic enzymes gene namely CYP19A1 and P450scc. Moreover, DCI may modulate the stimulatory effects on steroidogenic genes mediated by both gonadotrophins and insulin.

The efficiency of the cultural system in which DCI treatments affected the genes regulation in hGCs primary cultures was evaluated trough the analysis of the expression of $\beta 3$ integrin gene. Integrins are membrane receptors involved in cells-extracellular matrices adhesion and in the signal transduction that are differentially

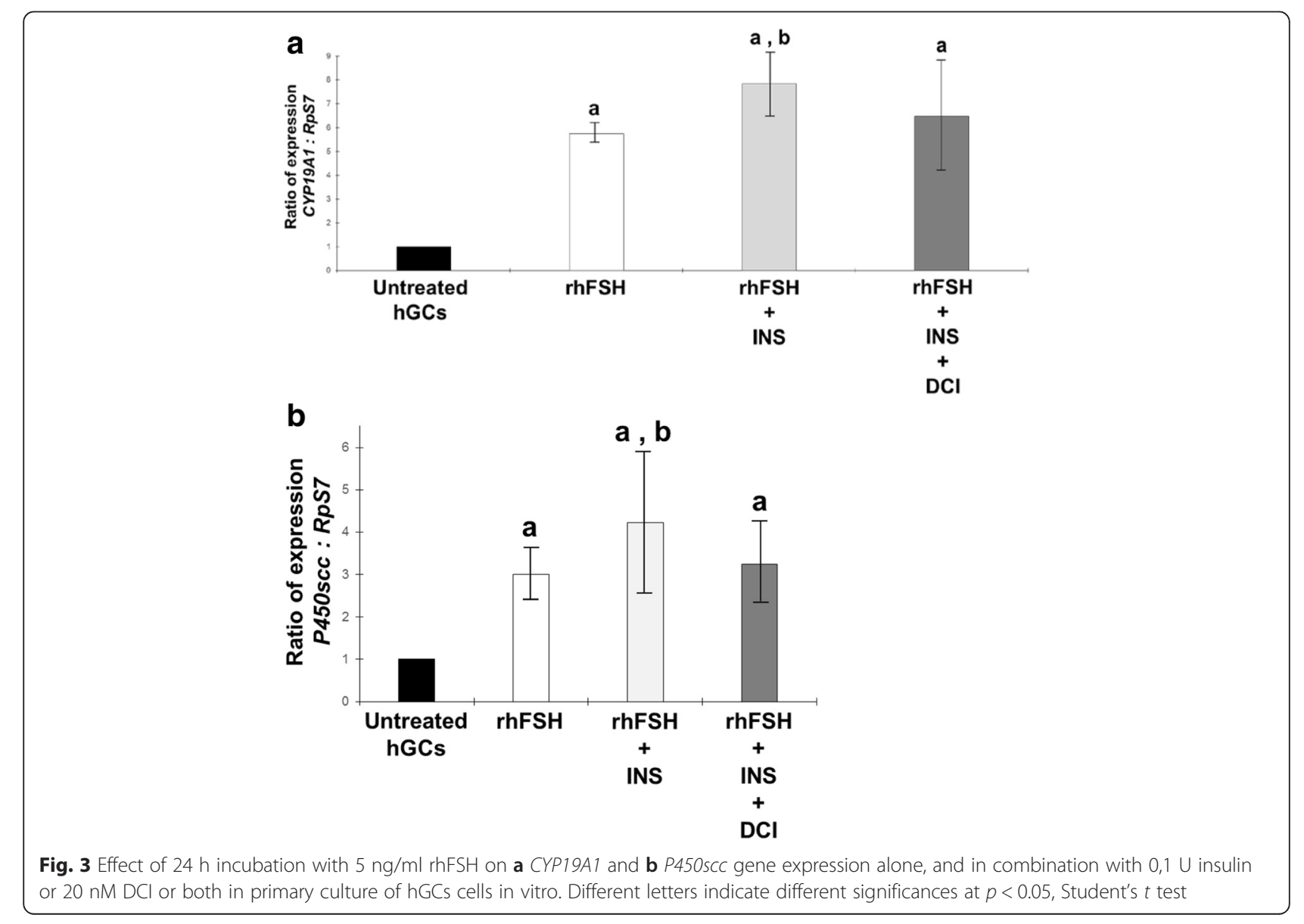




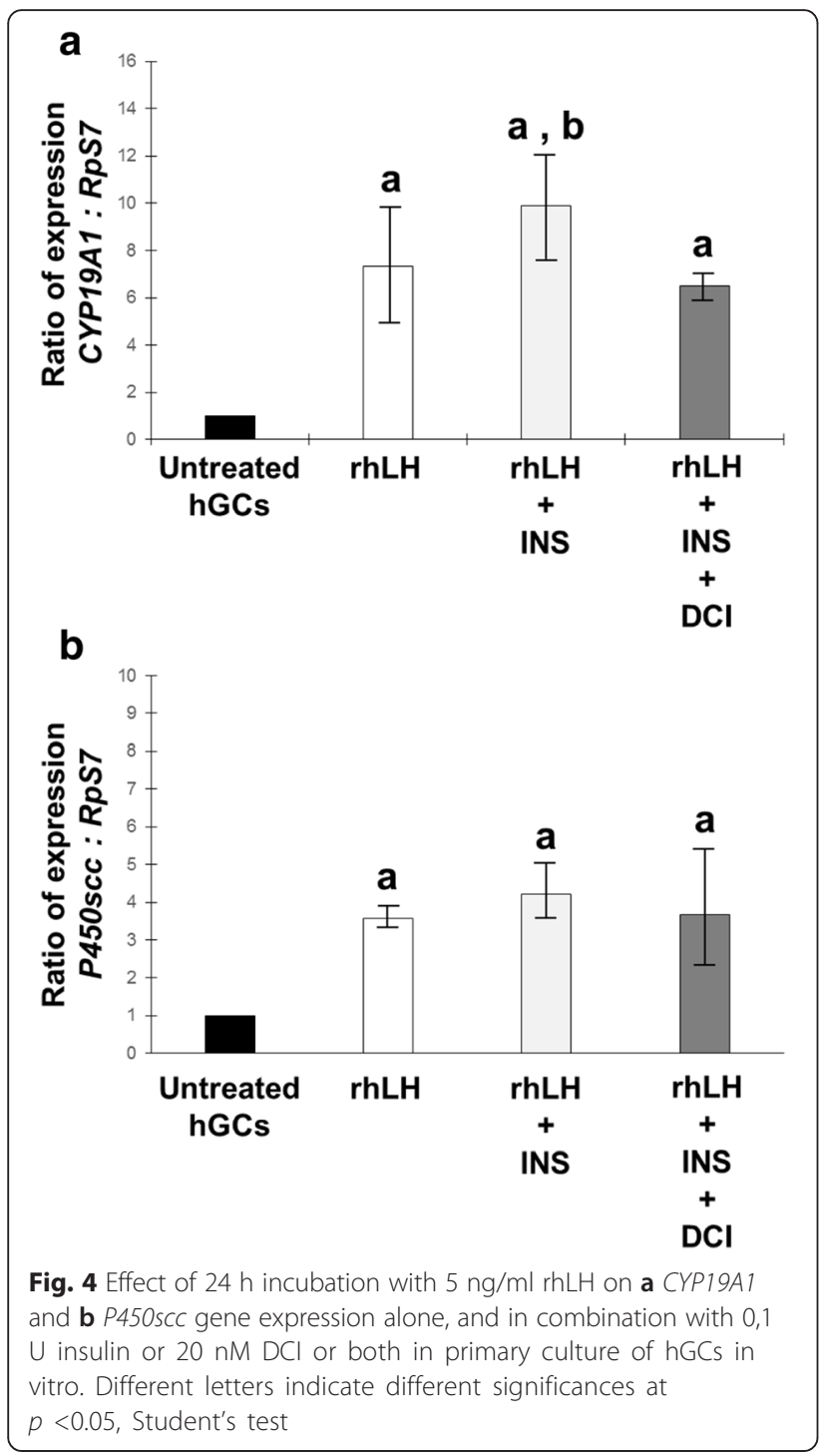

and stage-specifically expressed on hGCs [24]. It was shown that integrins are able to regulate different hGCs functions [25] as well as the corpus luteum formation $[26,27]$. For these reasons, it was hypothesized a possible role of integrins during folliculogenesis [28-30]. Moreover, in a different study conducted to evaluate a possible anti-metastasis effects of D-pinitol, a 3-methoxy DCI analogue, in human prostate cancer cells, it was demonstrated that noncytotoxic concentrations of Dpinitol reduced mRNA and cell surface expression of the $\beta 3$ integrin fraction on prostate cancer cells [31]. Based on the percentage of viable cells after the Trypan Blue exclusion assay, increasing concentrations of DCI were able to reduce the $\beta 3$ integrin gene expression in all the hGCs primary cultures employed in this study.

In addition, our analyses show that DCI acts directly on steroidogenic enzymes gene regulation of hGCs reducing mRNA expression of both CYP19A1 and

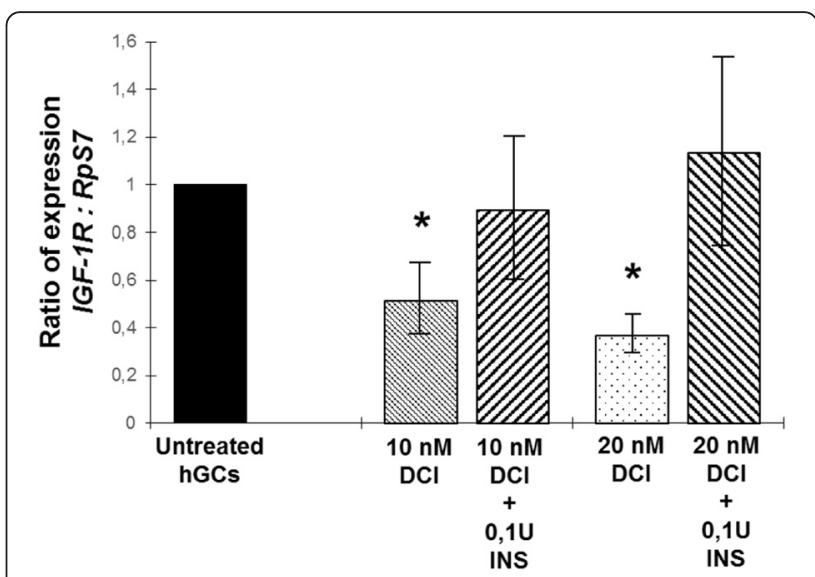

Fig. 5 Dose-response effect of $24 \mathrm{~h}$ of incubation with $10 \mathrm{nM}$ or 20 $\mathrm{nM} \mathrm{DCl}$ alone or in combination with 0,1 U insulin on IGFIR gene expression in primary culture of hGCs in vitro by RT-qPCR. Significant differences versus untreated controls were marked by ${ }^{*} p<0.05$, Student's t-test

P450scc genes in dose-response manner. P450scc enzymes catalyze many reactions involved in synthesis of cholesterol and steroids and togheter with the aromatase CYP19A1 are required to regulate estradiol and progesterone production within the ovary [32].

However, because the mature granulosa-lutein cells used for this in vitro study may not reflect the in vivo condition, the experiments were also conducted in presence of gonadotrophins and insulin. Both the gonadotrophins (alone or in combination) induce expression of CYP19A1 and P450scc genes [33, 34] although gonadotrophin-related profile of gene expression exists [35, 36]. It is also widely demonstrated that insulin plays a role in the ovarian functions by enhancing the gonadotrophin effects as showed in theca cells $[37,38]$ and in granulosa cells $[39,40]$. In our experimental model, incubation with rhFSH or rhLH were able to induce CYP19A1 and P450scc gene expression according with previously published data [36]. Moreover, our data confirmed that insulin could influence steroidogenesis by increasing the stimulatory effects of $\mathrm{LH}$ and FSH, as showed in our study, by increasing the expression of steroidogenic enzyme genes. Interestingly the positive effect of insulin on gonadotrophin-stimulated hGCs was counter-acted by the presence of DCI. However, the hGCs cultured in presence of DCI were still responsiveness to gonadotrophins as the CYP19A1 and P450scc were significatively induced if compared to the untreated hGCs control.

Since it was also reported that DCI plays a role as second messengers in the classical phosphorylation signaling pathways activated by insulin triggering the activation of $\mathrm{Mg}^{2+}$-dependent protein phosphatases (MPPs) family which control the glucose metabolism [5], we investigate the effects of co-treatment with DCI and insulin in hGCs. 
Notoriously, insulin exerts its function not only by binding insulin receptors present on the surface of target cells but also functioning as ligand for IGF-1R [41]. The typical ligand for IGF-1R is the hormone insulin-like growth factor (IGF) that is considered to have cogonadotrophin effects.

In the last years one of the most studied of the in vivo pathology related to infertility was the PCOS. The PCOS is characterized by elevated levels of insulin and IGF-1R [42] and it has been hypothesized that this could influence the pathogenesis of the syndrome and the alterations of sexual steroids commonly frequent in patients affected by PCOS. IGF-1R is present on the cellular membrane of hGCs [43] and it has been demonstrated that different insulin sensitizer drugs such metformin are able to modulate gene expression [20, 44].

In the present study, we showed not only that DCI is able to balance the additional stimulatory effect on steroidogenic enzyme gene of gonadotrophins stimulated hGCs, but also we firstly demonstrated that incubation of hGCs with increasing dosage of DCI resulted in a decreased IGF-1R expression in a dose-dependency manner.

\section{Conclusions}

In conclusion, in the present study we could confirm the effect of insulin as co-gonadotrophin on granulosa cells from the ovaries and we could demonstrate that DCI, an insulin-sensitizers counteract this action. This was evident when the expression of several genes was investigated, such as aromatase CYP19A1, P450scc and IGF-1 receptor. The ability of DCI to modulate in vitro ovarian activity of insulin could at least in part explain its beneficial effect when used as treatment for conditions associated to insulin-resistance.

\section{Acknowledgements \\ None/Not applicable.}

\section{Funding}

Not applicable.

\section{Availability of data and materials}

Data sharing not applicable to this article as no datasets were generated or analyzed during the current study. All data generated or analysed during this study are included in this published article.

\section{Authors' contributions \\ SS and ALM conceived the study and the experimental design, performed literature searches, analyzed and interpreted data and wrote the manuscript. SS performed all the experiments and the statistical analysis. FM, DT, JL provided support for all the experiments and the primary granulosa cell cultures. SX, TM, DT, CA, AT and SG provided human granulosa cells and revised the manuscript. All authors read and approved the final manuscript.}

\section{Competing interests}

The authors declare that they have no competing interests.

\section{Consent for publication}

Not applicable.
Ethics approval and consent to participate

Study approval was obtained from the local ethics committee and informed, written consent was obtained from each patient.

\section{Author details}

${ }^{1}$ Mother-Infant Department, University of Modena and Reggio Emilia, Via del pozzo 41, 41100 Modena, Italy. ${ }^{2}$ University of Modena and Reggio Emilia and Clinica Eugin Modena, Modena, Italy.

Received: 5 July 2016 Accepted: 23 August 2016

Published online: 31 August 2016

\section{References}

1. Thomas RM, Nechamen CA, Mazurkiewicz JE, Ulloa-Aguirre A, Dias JA. The adapter protein APPL1 links FSH receptor to inositol 1, 4, 5-trisphosphate production and is implicated in intracellular Ca (2+) mobilization. Endocrinology. 2011;152:1691-701.

2. Sun $T H$, Heimark DB, Nguygen T, Nadler JL, Larner J. Both myo-inositol to chiro-inositol epimerase activities and chiro-inositol to myo-inositol ratios are decreased in tissues of GK type 2 diabetic rats compared to Wistar controls. Biochem Biophys Res Commun. 2002;293(3):1092-8.

3. Steadman KJ, Burgoon MS, Schuster RL, Lewis BA, Edwardson SE, Obendorf RL. J. Fagopyritols, D-chiro-inositol, and other soluble carbohydrates in buckwheat seed milling fractions. J Agric Food Chem. 2000;48(7):2843-7.

4. Xia T, Wang Q. D-chiro-inositol found in Cucurbita ficifolia (Cucurbitaceae) fruit extracts plays the hypoglycaemic role in streptozocin-diabetic rats. J Pharm Pharmacol. 2006;58(11):1527-32.

5. Grummer RR, Armentano LE, Marcus MS. Lactation response to short-term abomasal infusion of choline, inositol, and soy lecithin. J Dairy Sci. 1987:70(12):2518-24.

6. Sim SY, Chin SL, Tan JL, Brown SJ, Cussons AJ, Stuckey BG. Polycystic ovary syndrome in type 2 diabetes: does it predict a more severe phenotype? Fertil Steril. 2016; doi: 10.1016/j.fertnstert.2016.06.040.

7. Baillargeon JP, Nestler JE, Ostlund RE, Apridonidze T, Diamanti-Kandarakis E. Greek hyperinsulinemic women, with or without polycystic ovary syndrome, display altered inositols metabolism. Hum Reprod. 2008;23:1439-46.

8. luorno MJ, Jakubowicz, Baillargeon JP, Dillon P, Gunn RD, Allan G, Nestler JE. Effects of d-chiroinositol in lean women with the polycystic ovary syndrome. Endocr Pract. 2002;8:417-23.

9. Baillargeon JP, Diamanti-Kandarakis E, Ostlund RE, Apridonidze T, luorno MJ, Nestler JE. Altered D-chiro-inositol urinary clearance in women with polycystic ovary syndrome. Diabetes Care. 2006;29:300-5.

10. Jung TS, Hahm JR, Kim JJ, Jung JH, Kang MY, Moon SW, Lee KW, Kim HC, Lee JD, Kim JH, Kim DR, Chung SI. Determination of urinary Myo-/Chiro-inositol ratios from Korean diabetes patients. Yonsei Med J. 2005;46(4):532-8.

11. Larner J. D-chiro-inositol in insulin action and insulin resistance-oldfashioned biochemistry still at work. IUBMB Life. 2001;51:139-48.

12. Larner J, Brautigan DL, Thorner MO. D-chiro-inositol glycans in insulin signaling and insulin resistance. Mol Med. 2010;16(11-12):543-51.

13. Unfer V, Carlomagno G, Papaleo E, Vailati S, Candiani M, Baillargeon JP. Hyperinsulinemia alters myoinositol to d-chiroinositol ratio in the follicular fluid of patients with PCOS. Reprod Sci. 2014;21(7):854-8.

14. Nestler JE, Jakubowicz DJ, Reamer P, Gunn RD, Allan G. Ovulatory and metabolic effects of D-chiro-inositol in the polycystic ovary syndrome, in N. Engl J Med. 1999;340(17):1314-20.

15. Nestler JE, Jakubowicz DJ, luorno MJ. Role of inositolphosphoglycan mediators of insulin action in the polycystic ovary syndrome. J Pediatr Endocrinol Metab. 2000;13 Suppl 5:1295-8.

16. Mu YM, Yanase T, Nishi Y, Waseda N, Oda T, Tanaka A, Takayanagi R, Nawata H. Insulin sensitizer, troglitazone, directly inhibits aromatase activity in human ovarian granulosa cells. Biochem Biophys Res Commun. 2000;271(3):710-3.

17. Silva JM, Price CA. Insulin and IGF-I are necessary for FSH-induced cytochrome P450 aromatase but not cytochrome P450 side-chain cleavage gene expression in oestrogenic bovine granulosa cells in vitro. J Endocrinol. 2002;174(3):499-507.

18. Sahmi M, Nicola ES, Price CA. Hormonal regulation of cytochrome P450 aromatase mRNA stability in non-luteinizing bovine granulosa cells in vitro. J Endocrinol. 2006;190(1):107-15.

19. Rice S, Elia A, Jawad Z, Pellatt L, Mason HD. Metformin inhibits folliclestimulating hormone (FSH) action in human granulosa cells: relevance to polycystic ovary syndrome. J Clin Endocrinol Metab. 2013;98(9):1491-500. 
20. Fuhrmeister IP, Branchini G, Pimentel AM, Ferreira GD, Capp E, Brum IS, von Eye Corleta $\mathrm{H}$. Human granulosa cells: insulin and insulin-like growth factor-1 receptors and aromatase expression modulation by metformin. Gynecol Obstet Invest. 2014;77(3):156-62.

21. Ia Marca A, Morgante G, Palumbo M, Cianci A, Petraglia F, De Leo V. Insulinlowering treatment reduces aromatase activity in response to folliclestimulating hormone in women with polycystic ovary syndrome. Fertil Steril. 2002;78(6):1234-9.

22. Nordhoff $V$, Sonntag B, von Tils D, Gotte M, Schüring AN, Gromoll J, Redmann K, Casarini L, Simoni M. Effects of the FSH receptor gene polymorphism p.N680S on CAMP and steroid production in cultured primary human granulosa cells. Reprod Biomed Online. 2011;23:196-203.

23. Livak KJ, Schmittgen TD. Analysis of relative gene expression data using real-time quantitative $P C R$ and the $2(-$ delta delta $C(T))$ method. Methods. 2001;25(4):402-8.

24. Bronson RA, Fusi FM. Integrins and human reproduction. Mol Hum Reprod. 1996:2:153-68

25. Berisha B, Schams D, Rodler D, Sinowatz F, Pfaffl MW. Expression and localization of members of the thrombospondin family during final follicle maturation and corpus luteum formation and function in the bovine ovary. J Reprod Dev. 2016. PMID: 27396384

26. Fujiwara H, Honda T, Ueda M, Nakamura K, Yamada S, Maeda M, Mori T. Laminin supresses progesterone production by human luteinizing granulosa cells via interaction with integrin a6ß1. J Clin Endocrinol Metab. 1997:82:2122-8.

27. Honda T, Fujiwara H, Yamada S, Fujita K, Nakamura K, Nakayama T, Higuchi T, Ueda M, Maeda M, Mori T. Integrin a5 is expressed on human luteinizing granulosa cells during corpus luteum formation, and its expression is enhanced by human chorionic gonadotropin in vitro. Mol Hum Reprod. 1997;3:979-84

28. Takao Y, Fujiwara H, Yamada S, Hirano T, Maeda M, Fujii S, Ueda M. CD9 is expressed on the cell surface of human granulosa cells and associated with integrin a6ß1. Mol Hum Reprod. 1999;5:303-10.

29. Yamada S, Fujiwara H, Hona T, Higuchi T, Nakayama T, Inoue T, Maeda M, Fujii S. Human granulosa cells express integrin a2 and collagen type IV: possible involvement of collagen type IV in granulosa cell luteinization. Mol Hum Reprod. 1999;5:607-17.

30. Monniaux D, Huet-Calderwood C, Le Bellego F, Fabre S, Monget P, Calderwood DA. Integrins in the ovary. Semin Reprod Med. 2006;4:251-61.

31. Lin TH, Tan TW, Tsai TH, Chen CC, Hsieh TF, Lee SS, Liu HH, Chen WC, Tang $\mathrm{CH}$. D-pinitol inhibits prostate cancer metastasis through inhibition of aV $\beta 3$ integrin by modulating FAK, c-Src and NF-kB pathways. Int J Mol Sci. 2013;14(5):9790-802.

32. Hanukoglu I. Steroidogenic enzymes: structure, function, and role in regulation of steroid hormone biosynthesis. J Steroid Biochem Mol Biol. 1992;43(8):779-804.

33. Urban RJ, Garmey JC, Shupnik MA, Veldhuis JD. Follicle-stimulating hormone increases concentrations of messenger ribonucleic acid encoding cytochrome P450 cholesterol side-chain cleavage enzyme in primary coltures of porcine granulosa cells. Endocrinology. 1991;128(4):2000-7.

34. Santen RJ, Brodie H, Simpson ER, Siiteri PK, Brodie A. History of aromatase: saga of an important biological mediator and therapeutic target. Endocr Rev. 2009;30:343-75.

35. Yong EL, Hillier SG, Turner M, Baird DT, Ng SC, Bongso A, Ratnam SS. Differential regulation of cholesterol side-chain cleavage (P450scC) and aromatase (P450arom) enzyme mRNA expression by gonadotropins and cyclic AMP in human granulosa cells. J Mol Endocrinol. 1994;12(2):239-49.

36. Sacchi S, D'lppolito G, Sena P, Marsella T, Tagliasacchi D, Maggi E, Argento C, Tirelli A, Giulini S, La Marca A. The anti-müllerian hormone (AMH) acts as a gatekeeper of ovarian steroidogenesis inhibiting the granulosa cell response to both FSH and LH. J Assist Reprod Genet. 2016;33(1):95-100.

37. Nestler JE, Jakubowicz DJ, de Vargas AF, Brik C, Quintero N, Medina F. Insulin stimulates testosterone biosynthesis by human thecal cells from women with polycystic ovary syndrome by activating its own receptor and using inositolglycan mediators as the signal transduction system. J Clin Endocrinol Metab. 1998;83(6):2001-5.

38. Cadagan D, Khan R, Amer $\mathrm{S}$. Thecal cell sensitivity to luteinizing hormone and insulin in polycystic ovarian syndrome. Reprod Biol. 2016;16(1):53-60.

39. Nestler JE, Strauss 3rd JF. Insulin as an effector of human ovarian and adrenal steroid metabolism. Endocrinol Metab Clin North Am. 1991;20(4):807-23.
40. Vanttinen T, Liu J, Hyden-Granskog C, Parviainen M, Penttila I, Voutilainen R, Voutilainen $R$. Regulation of immunoreactive inhibin a and $B$ secretion in cultured human granulosa-luteal cells by gonadotropins, activin A and insulin-like growth factor type-1 receptor. J Endocrinol. 2000;167:289-94.

41. Garwood CJ, Ratcliffe LE, Morgan SV, Simpson JE, Owens H, VazquezVillaseñor I, Heath PR, Romero IA, Ince PG, Wharton SB. Insulin and IGF1 signalling pathways in human astrocytes in vitro and in vivo; characterisation, subcellular localisation and modulation of the receptors. Mol Brain. 2015;8:51.

42. Indran IR, Lee BH, Yong EL. Cellular and Animal Studies: Insights into Pathophysiology and Therapy of PCOS. Best Pract Res Clin Obstet Gynaecol 2016; doi: 10.1016/j.bpobgyn.2016.03.006.

43. Baumgarten SC, Convissar SM, Fierro MA, Winston NJ, Scoccia B, Stocco C IGF1R signaling is necessary for FSH-induced activation of AKT and differentiation of human cumulus granulosa cells. J Clin Endocrinol Metab. 2014;99(8):2995-3004.

44. Lee MS, Kim SH, Kim DS, Min KS, Yoon JT. Metformin enhances the action of insulin on porcine granulosa-lutein cells in vitro. Anim Reprod Sci. 2012;136(1-2):100-7.

\section{Submit your next manuscript to BioMed Central and we will help you at every step:}

- We accept pre-submission inquiries

- Our selector tool helps you to find the most relevant journal

- We provide round the clock customer support

- Convenient online submission

- Thorough peer review

- Inclusion in PubMed and all major indexing services

- Maximum visibility for your research

Submit your manuscript at www.biomedcentral.com/submit
C Biomed Central 